\title{
Hispolon from Phellinus linteus induces apoptosis and sensitizes human cancer cells to the tumor necrosis factor-related apoptosis-inducing ligand through upregulation of death receptors
}

\author{
JI-HUN KIM $^{1 *}$, YU CHUL KIM ${ }^{2 *}$ and BYOUNGDUCK PARK ${ }^{3}$ \\ ${ }^{1}$ Department of Biotechnology, Research Institute (RIBHS) and College of Biomedical and Health Science, \\ Konkuk University, Chungju, Chungbuk 27478; ${ }^{2}$ Discovery Research Center, C\&C Research Laboratories, Suwon-si, \\ Gyeonggi-do 440-746; ${ }^{3}$ College of Pharmacy, Keimyung University, Dalseo-Gu, Daegu 704-701, Republic of Korea
}

Received September 21, 2015; Accepted October 30, 2015

DOI: 10.3892/or.2015.4440

\begin{abstract}
The tumor necrosis factor-related apoptosis-inducing ligand (TRAIL) is a potent anticancer agent possessing the ability to induce apoptosis in various cancer cells but not in non-malignant cells. However, certain type of cancer cells are resistant to TRAIL-induced apoptosis and some acquire resistance after the first treatment. So development of an agent that can reduce or avoid resistance in TRAIL-induced apoptosis has garnered significant attention. The present study evaluated the anticancer potential of hispolon in TRAIL-induced apoptosis and indicated hispolon can sensitize cancer cells to TRAIL. As the mechanism of action was examined, hispolon was found to activate caspase-3, caspase- 8 and caspase- 9 , while downregulating the expression of cell survival proteins such as cFLIP, Bcl-2 and Bcl-xL and upregulating the expression of Bax and truncated Bid. We also found hispolon induced death receptors in a non-cell type-specific manner. Upregulation of death receptors by hispolon was found to be p53-independent but linked to the induction of CAAT enhancer binding protein homologous protein (CHOP). Overall, hispolon was demonstrated to potentiate the apoptotic effects of TRAIL through downregulation of anti-apoptotic proteins and upregulation of death receptors linked with CHOP and pERK elevation.
\end{abstract}

\section{Introduction}

According to National Vital Statistics System (2013), cancer is the second major cause of death in US. Despite improvements

Correspondence to: Dr Byoungduck Park, College of Pharmacy, Keimyung University, 1095 Dalgubeoldaero, Dalseo-Gu, Daegu 704-701, Republic of Korea

E-mail: bdpark@kmu.ac.kr

*Contributed equally

Key words: TRAIL-induced apoptosis, hispolon, ERK, death receptor, c-FLIP, Bcl-2 in diagnostic techniques, clinical intervention and increased public concern, the prevalence of cancer in developed countries continues to rise (1). The standard medical treatment for cancer includes surgery of the cancerous tumor followed by radiotherapy and/or chemotherapy to kill the remaining cancerous cells. Most therapeutic strategies focus on overcoming two key hallmarks of cancer: i) excessive proliferation and ii) apoptosis resistance (2). However, a more certain cure is induction of apoptosis rather than inhibition of proliferation because the former is able to eliminate cancer cells while later may only limit tumor outgrowth. For this reason, the development of apoptotic agents has become of great interest in cancer research.

The tumor necrosis factor (TNF)-related apoptosis inducing ligand (TRAIL) was first identified based on its sequence homology to TNF and CD95L $(3,4)$, and was found to induce apoptosis in a wide range of human cancer cell lines (3-6) while leaving normal tissues intact (7-9). Although five receptors have been identified as TRAIL recognition partner, only 2 receptors, DR4 (TRAIL-R1) and DR5 (TRAIL-R2), have cytoplasmic death domains that participate in apoptotic event upon TRAIL binding (10). Based on this knowledge, a fully human monoclonal agonist antibody against human DR5 has been developed as an anticancer therapy (11). However, cancer cells frequently acquire TRAIL resistance during the progression of the tumor (12). TRAIL resistance mechanisms have not yet been clearly elucidated but numerous mechanisms to manage TRAIL-induced apoptosis have been reported. Dysfunction of DR4 and DR5, and defects of essential component for assembly of the death-inducing signaling complex such as Fas-associated death domain (FADD) and caspase-8, can lead to TRAIL resistance (13-15). Overexpression of cellular FADD-like interleukin-1 $\beta$-converting enzyme inhibitory protein (cFLIP) $(16,17)$, X-linked inhibitor of apoptosis (XIAP) (18), Mcl-1, nuclear factor (NF)- $\mathrm{B}(19,20)$, Bcl-2 and Bcl-xL (21), and loss of Bax and Bak function also contribute to TRAIL resistance in cancerous cell (22). Thus, agents capable of evading resistance mechanisms to TRAIL-induced apoptosis are receiving significant attention from cancer therapy community. 
Hispolon, a phenol compound isolated from Phellinus linteus (PL) and used as traditional medicinal mushroom in Asia, possesses various functions including anti-inflammatory, anti-proliferative and antioxidant effects (23-25). Hispolon also has an antitumor effect inhibiting tumor cell growth or metastasis in various tumor types $(23,26-30)$. For example, hispolon showed anti-proliferative effects in breast and bladder cancer cells (26), proapoptotic effect on human epidermoid KB cell and suppression of human hepatoma cell metastasis (27). Studies on its antitumor mechanism show downregulation of MDM2 via activated extracellular signal-regulated kinase $1 / 2($ ERK1/2) can induce the death of $\mathrm{KB}$ cells through a mitochondria-mediated apoptotic pathway and reduce expression of matrix metalloproteinase-2 (MMP-2), (MMP-9) and urokinase-type plasminogen activator (uPA).

In the present study, the ability of hispolon to modulate TRAIL-induced apoptosis in human colon cancer cells was investigated, as well as the subsequent mechanism of action. Hispolon was found to enhance TRAIL-induced apoptosis through the upregulation of pro-apoptotic proteins, downregulation of cell survival proteins and upregulation of death receptors.

\section{Materials and methods}

Materials. Hispolon was kindly provied by Dr B.B. Aggarwal, MD Anderson Cancer Center. Soluble recombinant human TRAIL was purchased from PeproTech (Rocky Hill, NJ, USA). Penicillin, streptomycin, Dulbecco's modified Eagle's medium, RPMI-1640 and fetal bovine serum were obtained from Invitrogen (Carlsbad, CA, USA). Soluble antibodies against Bcl-2, c-FLIP, Bcl-xL, DR4, Bid, Bax, CAAT enhancer binding protein homologous protein (CHOP), p53, procaspase-3 and procaspase- 8 were obtained from Santa Cruz Biotechnology (Santa Cruz, CA, USA). The DR5 antibody was purchased from ProSci, Inc. (Poway, CA, USA), anti XIAP antibody was from BD Biosciences. Antibodies against caspase- 9 and cleaved caspase- 8 were purchased from Cell Signaling Technology Inc. (Danvers, MA, USA). Mouse monoclonal anti- $\beta$-actin antibody was purchased from Sigma (St. Louis, MO, USA).

Cell lines. Human colon adenocarcinoma HCT-116, embryonic kidney carcinoma A293, multiple myeloma U-266 cells were obtained from American Type Culture Collection (Manassas, VA, USA). Human myeloid leukemia KBM-5 cells were kindly supplied by Dr Nicholas Donato (University of Michigan Comprehensive Cancer Center). Human colon cancer cell line HCT-116 was cultured in McCoy's 5A medium supplemented with $10 \%$ fetal calf serum and penicillin/streptomycin (Invitrogen). KBM-5 cells were cultured in Iscove's modified Dulbecco's medium with $15 \%$ fetal bovine serum. U-266 cells were cultured in RPMI-1640 with $10 \%$ fetal bovine serum, and A293 cells were cultured in Dulbecco's modified Eagle's medium, $100 \mathrm{U} / \mathrm{ml}$ penicillin and $100 \mathrm{mg} / \mathrm{ml}$ streptomycin.

Liveldead assay. To measure apoptosis of cells, we used the live/dead assay (Invitrogen), which assesses intracellular esterase activity and plasma membrane integrity. It is a two color fluorescence assay that simultaneously examines live and dead cells. The details of this assay were described before (31).

Cytotoxicity assay. The effects of hispolon on the cytotoxic potential of TRAIL were detected by measuring mitochondrial dehydrogenase activity using 3-(4,5-dimethylthiazol-2-yl)-2,5-diphenyltetrazolium bromide (MTT) as the substrate. This assay is based on the conversion of soluble MTT to purple colored insoluble formazan by mitochondrial dehydrogenases of viable cells. To examine the synergy between hispolon and TRAIL, cells were treated with hispolon alone $(25 \mu \mathrm{M})$ and TRAIL alone $(10,25$ and $50 \mathrm{ng} / \mathrm{ml})$ and the combination at fixed ratio. Cell viability was examined by MTT assay.

Western blot analysis. The effect of hispolon on the level of protein expression was studied by western blot analysis. The prepared whole cell extract was separated by SDS-PAGE. The separated proteins on the acrylamide gel were electro-transferred onto nitrocellulose membrane, stained with specific antibodies, and detected by an ECL regent (GE Healthcare, Pittsburgh, PA, USA).

Assay for cell surface expression of DR4 and DR5. HCT116 cells were treated with hispolon and washed with $1 \mathrm{X}$ PBS supplemented with $0.5 \%$ bovine serum albumin (BSA) after detachment with EDTA. Then cells were stained with phycoerythrin (PE)-conjugated mouse monoclonal anti-human DR4 and DR5 (clone 69036 and 71908, respectively) (R\&D Systems, Minneapolis, MN, USA) for $45 \mathrm{~min}$ at $4^{\circ} \mathrm{C}$ according to the manufacturer's instructions before washing and resuspension in a fluorescence-activated cell sorting buffer (1X PBS $+0.5 \%$ BSA). The cells were analyzed by flow cytometry using an excitation wavelength of $488 \mathrm{~nm}$.

\section{Results}

Hispolon upregulates TRAIL-induced apoptosis. Hispolon enhancement of TRAIL-induced apoptosis was examined and detected by live/dead assay in human colon cancer cells. As shown in Fig. 1A, when hispolon was added to HCT-116 cells already treated with TRAIL, a number of apoptotic cells were increased. The population of apoptotic cells, however, was not significantly influenced by adding either TRAIL or hispolon alone. TRAIL-induced apoptosis was upregulated by adding hispolon from 17 to $68 \%$ in HCT-116 cells. According to MTT assay, we found that hispolon reduced the viability of HCT-116 cells synergistically after pretreated with TRAIL (Fig. 1B, right panel).

TRAIL is known to mediate apoptosis through the activation of caspase-8, caspase- 9 and caspase-3, so the effect of hispolon on activation of these caspases and poly(ADP-ribose) polymerase (PARP) cleavage enhanced by TRAIL in HCT-116 cells was investigated. Although neither TRAIL nor hispolon had significant effect on the activation of these caspases or on cleavage of PARP, treatment of cells with combination TRAIL and hispolon enhanced activation of all caspases and ensuing PARP cleavage (Fig. 1C).

Hispolon downregulates the expression of anti-apoptotic proteins. Hispolon modulation of anti-apoptotic proteins 
A

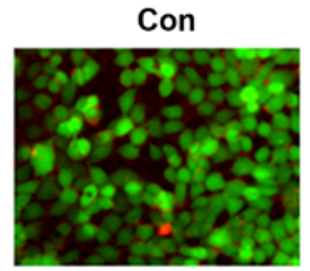

$4 \%$
HCT116

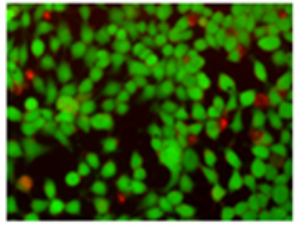

$11 \%$
TRAIL

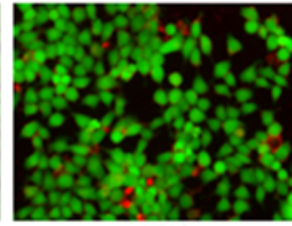

$17 \%$
His+TRAIL

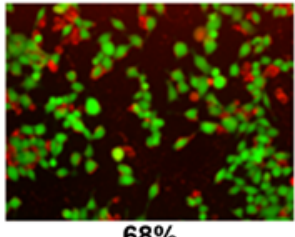

$68 \%$

B
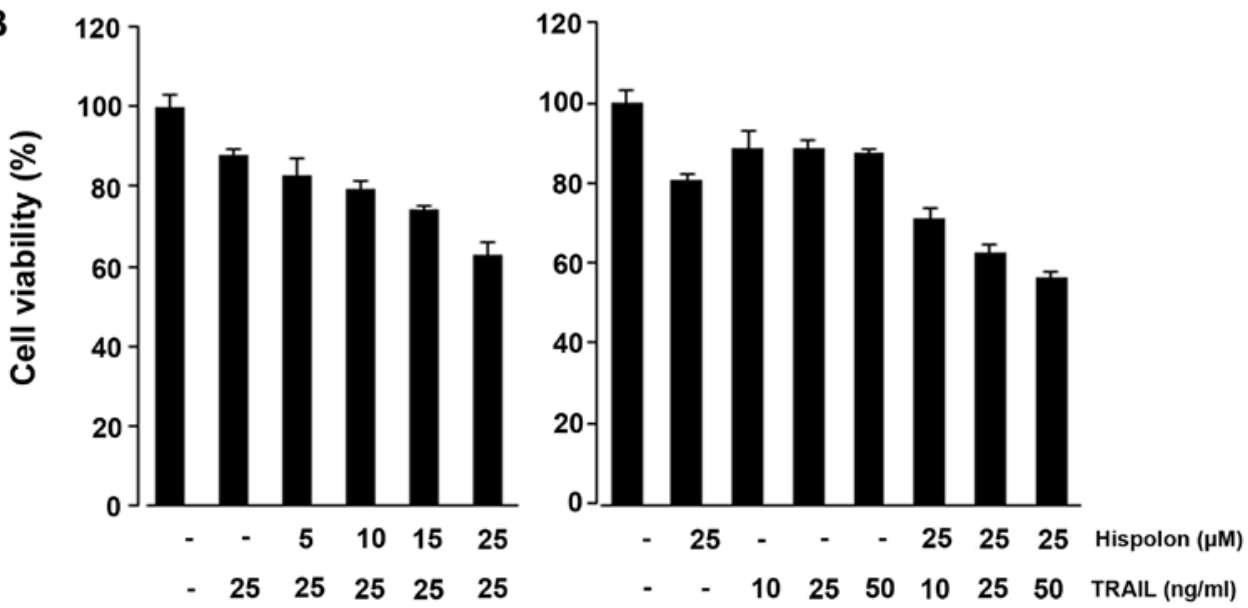

C

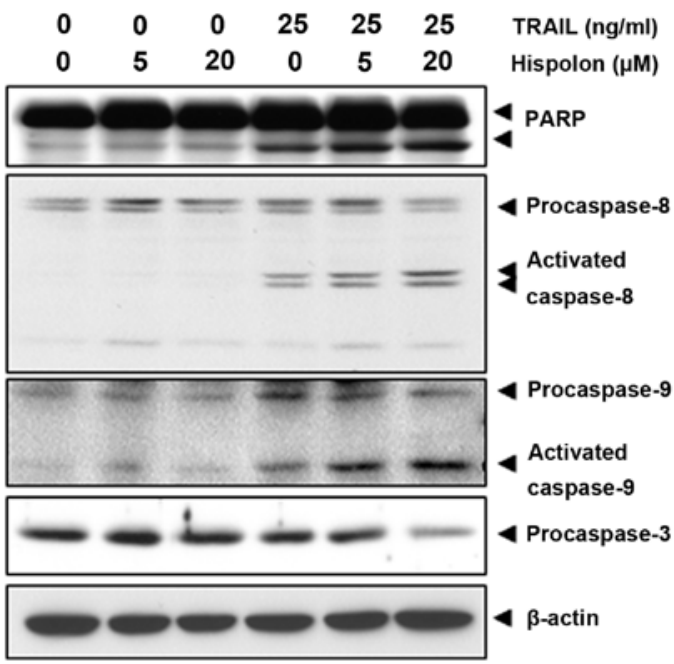

Figure 1. Hispolon enhances TRAIL-induced cell death in HCT-116, human colon cancer cells. (A) Cells were treated with hispolon (25 $\mu \mathrm{M})$, TRAIL $(50 \mathrm{ng} / \mathrm{ml})$ alone for $24 \mathrm{~h}$. After pretreatment of hispolon $(25 \mu \mathrm{M})$ for $12 \mathrm{~h}$, TRAIL $(50 \mathrm{ng} / \mathrm{ml})$ was added and incubated for $24 \mathrm{~h}$ (His + TRAIL). Then cell death was determined by the live/dead cell viability assay. (B, left) Cells were pretreated with the indicated concentrations of hispolon for $12 \mathrm{~h}$, washed with PBS to remove hispolon, and then cells were exposed to $25 \mathrm{ng} / \mathrm{ml}$ TRAIL. (B, right) Cells were pretreated with $25 \mu \mathrm{M}$ hispolon for $12 \mathrm{~h}$, washed with PBS to remove hispolon, and then cells were exposed to the indicated concentration of TRAIL for $24 \mathrm{~h}$. (C) Cells were pretreated with hispolon for $12 \mathrm{~h}$ and washed out. Then cells were treated with TRAIL for $24 \mathrm{~h}$. Whole-cell extracts were analyzed by western blot analysis using the indicated antibodies.

linked to TRAIL resistance in human colon cancer cells was examined. Results indicate the expression of c-FLIP, Bcl-2 and $\mathrm{Bcl}-\mathrm{xL}$ was strongly downregulated in a concentrationdependent manner, while the downregulation of XIAP was not visible (Fig. 2A). Time-dependent effect of hispolon on the expression of these cell survival proteins was also examined. As shown in Fig. 2B, c-FLIP, Bcl-2 and Bcl-xL were downregulated by hispolon in a time-dependent manner.

Hispolon upregulates the apoptotic progression. Whether hispolon regulates the expression of pro-apoptotic proteins,
Bid and Bax, was examined. Results showed that hispolon upregulated the expression of Bax in a concentration- and time-dependent manner in HCT-116 cells (Fig. 2C and D). The pro-apoptotic protein $\mathrm{Bid}$, in which $\mathrm{N}$-terminal helices are cleaved by caspase- 8 to the truncated active form for apoptosis was downregulated concentration- and time-dependently. These results suggest that hispolon can upregulate the apoptotic progression.

Hispolon upregulates expression of the death receptor. To understand further possible mechanisms of regulation of 
A

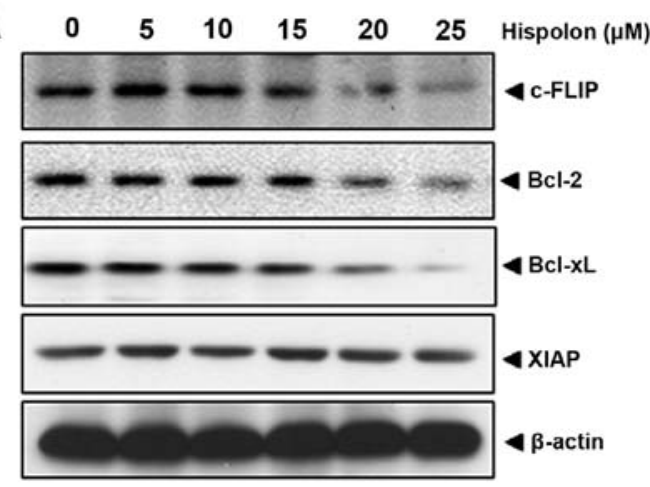

C

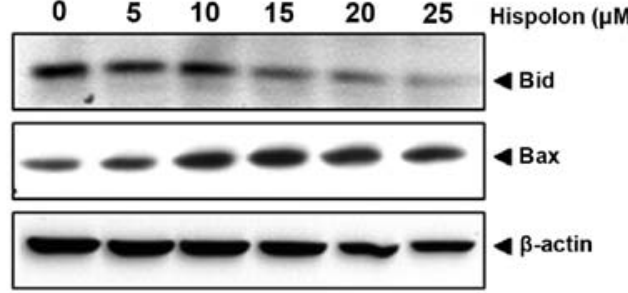

B

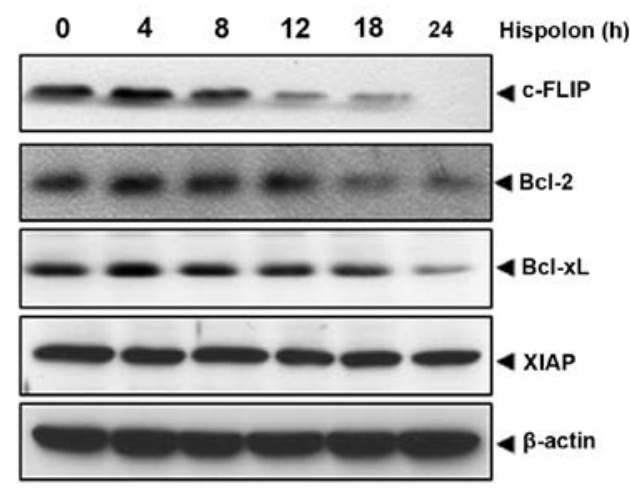

D

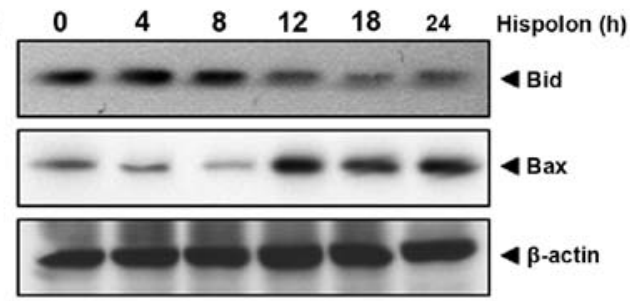

Figure 2. Hispolon regulates anti-apoptotic and pro-apoptotic protein expression. (A and B) For determining concentration-dependent regulation of anti-apoptotic proteins, HCT 116 cells were pretreated with the indicated concentration of hispolon for $24 \mathrm{~h}$. For determining time-dependent modulation of anti-apoptotic proteins, cells were treated with $25 \mu \mathrm{M}$ of hispolon for indicated time-intervals. Whole cell extracts were analyzed by western blot analysis using antibodies against c-FLIP, Bcl-2, Bcl-xL and XIAP. Membranes were stripped and reprobed with $\beta$-actin to verify equal protein loading. (C and D) For determining concentration and time-dependent regulation of pro-apoptotic proteins, cells were treated with hispolon at the indicated doses and times. The whole cell extracts were analyzed by western blot analysis using antibodies against Bid and Bax. The same blots were stripped and reprobed with $\beta$-actin to verify equal protein loading.

TRAIL-induced apoptosis by hispolon, the effect of hispolon on expression of the death receptor was investigated in human colon cancer cells. As shown in Fig. 3A and B, hispolon upregulated DR4 and DR5 expression in HCT116 cells concentration- and a time-dependently, but upregulation of DR4 was less pronounced. Result also indicated that treatment of cells with $25 \mu \mathrm{M}$ hispolon for 12-18 $\mathrm{h}$ was optimal for inducing DR4 and DR5. As shown in Fig. 3C, hispolon also increased expression of the death receptors on the cell surface, investigated by flow cytometry.

Upregulation of the death receptor is not cell type-dependent. We investigated whether upregulation of death receptor by hispolon is specific to human colon cancer cells. As shown in Fig. 3D, the results indicated that hispolon upregulated both DR4 and DR5 in chronic myeloid leukemia cell (KBM-5), multiple myeloma cell (U-266) and embryonic kidney carcinoma (A293). These results suggest that the upregulation of DRs by hispolon is not cell type-specific.

Hispolon upregulates CHOP. CHOP has been previously linked with the upregulation of DR5 expression $(32,33)$, thus CHOP in relation to hispolon-induced DRs was investigated. Our result indicated that hispolon induced the expression of CHOP, with optimum induction occurring at over $20 \mu \mathrm{M}$ (Fig. 4A).

Hispolon-induced upregulation of the death receptor is p53 independent. Because p53 is known to induce the TRAIL receptor, hispolon modulation of the expression of $\mathrm{p} 53$ in HCT-116 cells was investigated. As shown in Fig. 4A, the expression of p53 was not changed in colon cancer cells, suggesting that p53 is unnecessary for hispolon-induced upregulation of TRAIL receptors.

Activation of JNK by hispolon is unnecssary but activation of ERK is linked to the role of hispolon. Various studies reported the importance of MAPK activation in TRAIL receptor induction $(34,35)$. Thus, we investigated the hispolon-induced activation of ERK and JNK, respectively. When cells were treated with hispolon, phosphor-ERK was increased in a time-dependent manner, whereas hispolon could not induce JNK activation (Fig. 4B). These results suggest that hispolon-induced apoptosis is possibly linked to the ERK pathway, but not to the JNK pathway.

\section{Discussion}

TRAIL is a very promising cytokine molecule for anticancer therapy, but it has a limitation caused by the resistance developed by certain cancer types. The development of agents that sensitize cancer cells to TRAIL is important for the success of the promising TRAIL-based cancer therapy. In the present study, we showed that hispolon enhances TRAIL-induced apoptosis of human colon cancer cells and investigate the molecular mechanism of sensitizing human cancer cells to TRAIL.

Hispolon was identified to obviously enhance the TRAIL-induced apoptosis in HCT-116, human colon cancer cells, through live/dead and MTT assays. HCT-116 belongs to type II cells, classified based on how apoptosis induction is employed upon DISC activation (36). Type II cells have been 

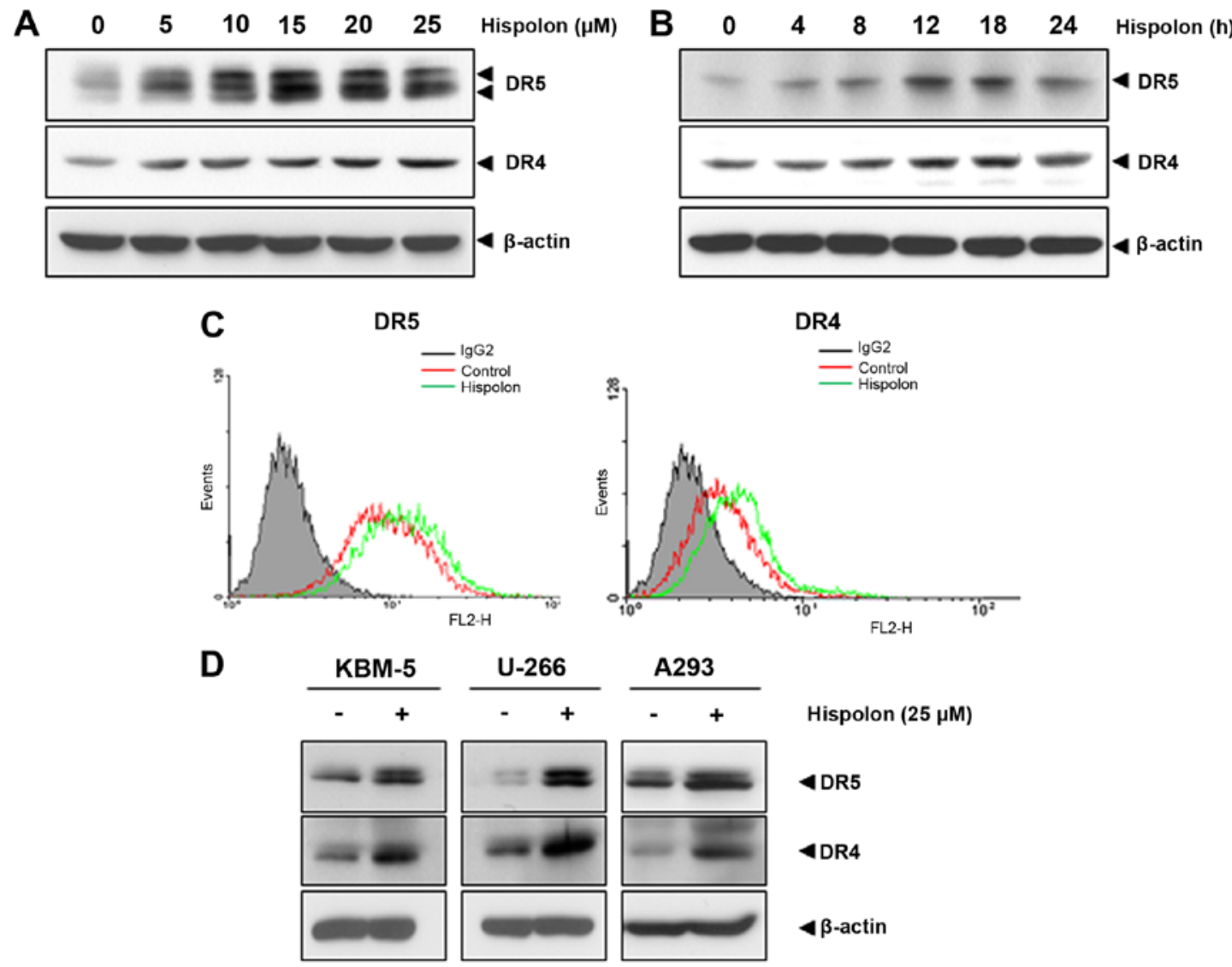

Figure 3. Hispolon upregulates DR4 and DR5 expression. (A and B) HCT 116 cells were treated with indicated concentrations of hispolon for $24 \mathrm{~h}$ (A) or with $25 \mu \mathrm{M}$ of hispolon for indicated times (B). The whole cell extracts were analyzed by western blot analysis using antibodies against DR4 and DR5. (C) Hispolon enhances cell surface expression of DR4 and DR5. Cells were treated with $25 \mu \mathrm{M}$ of hispolon for $24 \mathrm{~h}$, and cell surface expression of DRs was determined using phycoerythrin (PE)-conjugated DR4 and DR5 antibodies by flow cytometry. (D) Hispolon-induced upregulation of DR4 and DR5 is not cell type-specific. Human chronic myeloid leukemia (KBM-5), multiple myeloma (U-266) and embryonic kidney cancer (A293) cells were treated with $25 \mu$ M of hispolon for $24 \mathrm{~h}$. The whole cell extracts were analyzed by western blot analysis using DR4 and DR5 antibodies. The same blots were stripped and reprobed with $\beta$-actin to verify equal protein loading.
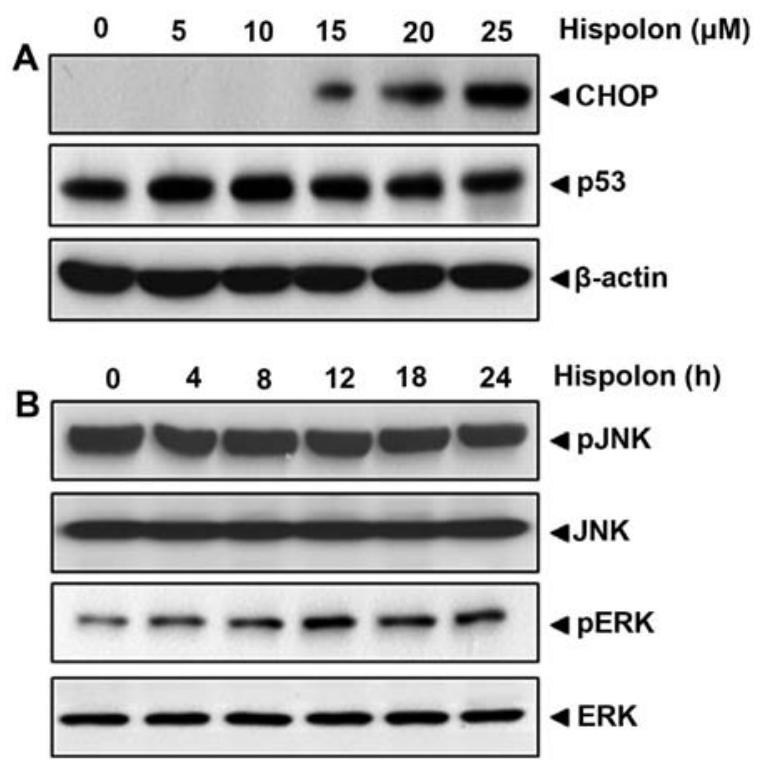

Figure 4. Hispolon upreuglates CHOP and activates ERK. (A) Cells were treated with the indicated concentration of hispolon for $24 \mathrm{~h}$. The whole cell extracts were analyzed by western blot analysis using antibodies against CHOP and $\mathrm{p} 53$. The same blots were stripped and reprobed with $\beta$-actin to verify equal protein loading. (B) Cells were treated with $25 \mu \mathrm{M}$ of hispolon and incubated for the indicated times, and whole cell extracts were analyzed by western blotting using pJNK, JNK, pERK and ERK antibodies. defined to be dependent on mitochondria for the induction of the Fas death receptor-mediated apoptosis, while type I cells are mitochondria-independent (37). For this reason, there is a significant possibility of a complicated mechanism for TRAIL-induced apoptosis in HCT-116. Considering the pivotal role of caspases in the initiation and execution of apoptosis, caspase activation by hispolon was examined. We found that hispolon activated caspase- 8 , caspase- 9 and caspase- 3 , enzymes known to be involved in type II TRAIL-induced apoptosis pathway. This activation of caspase was also supported by PARP cleavage, a known hallmark of apoptosis and caspase activation. Downregulation of cFLIP, an inhibitor of caspase- 8 , was also found and suggested that upregulation of caspase- 8 activity could be from reduced expression of cFLIP. However, XIAP, known to be a potent inhibitor of caspase-3 and caspase- 9 , was not regulated by hispolon, thus ruling out the possibility that upregulations of caspase- 3 and caspase- 9 are caused by downregulation of XIAP.

The expression of $\mathrm{Bcl}-2$ and $\mathrm{Bcl}-\mathrm{xL}$ was also downregulated by hispolon. These proteins have been linked to suppression of apoptosis by TRAIL, frequently found in TRAIL resistance in a variety of cancer cells including colon (38), breast (39) and kidney cancers (40). The reasons for downregulation of anti-apoptotic proteins including $\mathrm{Bcl}-2$ and $\mathrm{Bcl}-\mathrm{xL}$ have not 
been clearly elucidated. Previously, it was reported that hispolon downregulates $\mathrm{NF}-\kappa \mathrm{B}$ (41) as most anti-apoptotic proteins are regulated by $\mathrm{NF}-\kappa \mathrm{B}$. Taken together, hispolon-induced downregulation of these anti-apoptotic proteins may also be regulated by the downregulation of $N F-\kappa B$ in colon cancer cells. Our findings suggest pro-apoptosis proteins, Bax and Bid, also contribute to TRAIL-induced apoptosis. The results that upregulation of Bax and downregulation of Bid can be explained by the mitochondrial-dependent apoptosis mechanism through caspase-8-Bid-tBid-Bax pathway.

We further found that hispolon significantly induced the expression of both the TRAIL receptors, DR4 and DR5. We also demonstrated the upregulation of death receptors on the cell surface by hispolon. Moreover, hispolon-induced death receptor upregulation is not tissue-specific, which means hispolon can be applied in treatment to various cancer patients as a combination therapy with TRAIL. A few agents have been shown to upregulate the death receptor in human colon cancer cells including capsazepine (42) and azadirone (43). These results suggested that the death receptor is essential for TRAIL-induced apoptosis. Upregulation of the death receptor in HCT-116 by hispolon may play an important role in TRAIL-induced apoptosis similarly to other agents mentioned above.

The molecular mechanism of DR4 and DR5 induction in colon cancer cells was also investigated. Numerous mechanisms have been suggested for induction of this death receptor, including ROS generation, p53 induction and NF- $\mathrm{B}$, DNA damage-inducible transcript 3 (DDIT3), peroxisome proliferator-activated receptor and MAPK activation (33,44-46). $\mathrm{CHOP}$ is also known to be a regulator of the death receptor via binding of CHOP to the death receptor promoter $(32,33,47)$. We found that CHOP was upregulated by hispolon in HCT-116 cells and hispolon can induce the death receptor through $\mathrm{CHOP}$ mediated mechanism. We also found that hispolon-induced DR5 was related to ERK activation, but independent of JNK. In agreement of these observations, a previous study reported the important role of ERK in upregulation of death receptors by zerumbone (48). In addition, azadirone and gossypol also demonstrated that these molecules induce death receptor through activation of the ROS-ERK-CHOP pathway in human colon cancer cells. ROS was not examined when we explored this mechanism, however, ROS is known to be an up-stream regulator of JNK, p38 and ERK. In addition, hispolon induction of apoptosis through ROS-mediated mitochondria pathway was reported (28). Considering the information now available, hispolon may induce TRAIL-induced apoptosis through ROS-ERK-CHOP-mediated upregulation of the death receptor.

Another mechanism, induction of apoptosis through p53 was also investigated because of the importance of this pathway in the response to cell stress such as chemotherapy and radiotherapy. In this pathway, the upregulation of p53 is essential for an apoptosis event, however, hispolon could not induce p53 in HCT-116 cells. In other words, hispolon-induced apoptosis is not involved in the extrinsic apoptosis pathway, which corresponds to the type II classification of HCT-116.

Overall, our studies provide strong evidence that hispolon could potentiate TRAIL-induced apoptosis hypothetically through ROS-, ERK- and CHOP-mediated upregulation of death receptors. The enhancement of apoptosis by hispolon was also shown to be related to the upregulation of cell survival proteins and the upregulation of pro-apoptotic proteins. Hispolon combined with TRAIL may be a good candidate for anticancer therapy, however, further studies using animal models are needed to realize this combination anticancer therapy.

\section{Acknowledgements}

The present study was supported by the Basic Science Research Program through the National Research Foundation of Korea (NRF) funded by the Ministry of Science, ICT and Future Planning (NRF-2013R1A1A1062064).

\section{References}

1. Jemal A, Bray F, Center MM, Ferlay J, Ward E and Forman D: Global cancer statistics. CA Cancer J Clin 61: 69-90, 2011.

2. Hanahan D and Weinberg RA: Hallmarks of cancer: The next generation. Cell 144: 646-674, 2011.

3. Pitti RM, Marsters SA, Ruppert S, Donahue CJ, Moore A and Ashkenazi A: Induction of apoptosis by Apo-2 ligand, a new member of the tumor necrosis factor cytokine family. J Biol Chem 271: 12687-12690, 1996.

4. Wiley SR, Schooley K, Smolak PJ, Din WS, Huang CP, Nicholl JK, Sutherland GR, Smith TD, Rauch C, Smith CA, et al: Identification and characterization of a new member of the TNF family that induces apoptosis. Immunity 3: 673-682, 1995.

5. Tanaka M, Suda T, Yatomi T, Nakamura N and Nagata S: Lethal effect of recombinant human Fas ligand in mice pretreated with Propionibacterium acnes. J Immunol 158: 2303-2309, 1997.

6. Walczak H, Degli-Esposti MA, Johnson RS, Smolak PJ, Waugh JY, Boiani N, Timour MS, Gerhart MJ, Schooley KA, Smith CA, et al: TRAIL-R2: A novel apoptosis-mediating receptor for TRAIL. EMBO J 16: 5386-5397, 1997.

7. French LE and Tschopp J: The TRAIL to selective tumor death. Nat Med 5: 146-147, 1999.

8. Gura T: How TRAIL kills cancer cells, but not normal cells. Science 277: 768, 1997.

9. Walczak H, Miller RE, Ariail K, Gliniak B, Griffith TS, Kubin M, Chin W, Jones J, Woodward A, Le T, et al: Tumoricidal activity of tumor necrosis factor-related apoptosis-inducing ligand in vivo. Nat Med 5: 157-163, 1999.

10. Bhardwaj A and Aggarwal BB: Receptor-mediated choreography of life and death. J Clin Immunol 23: 317-332, 2003.

11. Doi T, Murakami H, Ohtsu A, Fuse N, Yoshino T, Yamamoto N, Boku N, Onozawa Y, Hsu CP, Gorski KS, et al: Phase 1 study of conatumumab, a pro-apoptotic death receptor 5 agonist antibody, in Japanese patients with advanced solid tumors. Cancer Chemother Pharmacol 68: 733-741, 2011.

12. Maksimovic-Ivanic D, Stosic-Grujicic S, Nicoletti F and Mijatovic S: Resistance to TRAIL and how to surmount it. Immunol Res 52: 157-168, 2012.

13. Fulda S,KüferMU,MeyerE,van ValenF,Dockhorn-DworniczakB and Debatin KM: Sensitization for death receptor-or drug-induced apoptosis by re-expression of caspase- 8 through demethylation or gene transfer. Oncogene 20: 5865-5877, 2001.

14. Eggert A, Grotzer MA, Zuzak TJ, Wiewrodt BR, Ho R, Ikegaki N and Brodeur GM: Resistance to tumor necrosis factor-related apoptosis-inducing ligand (TRAIL)-induced apoptosis in neuroblastoma cells correlates with a loss of caspase- 8 expression. Cancer Res 61: 1314-1319, 2001.

15. Bodmer JL, Holler N, Reynard S, Vinciguerra P, Schneider P, Juo P, Blenis J and Tschopp J: TRAIL receptor-2 signals apoptosis through FADD and caspase-8. Nat Cell Biol 2: 241-243, 2000.

16. Tepper CG and Seldin MF: Modulation of caspase-8 and FLICE-inhibitory protein expression as a potential mechanism of Epstein-Barr virus tumorigenesis in Burkitt's lymphoma. Blood 94: 1727-1737, 1999.

17. Okano H, Shiraki K, Inoue H, Kawakita T, Yamanaka T, Deguchi M, Sugimoto K, Sakai T, Ohmori S, Fujikawa K, et al: Cellular FLICE/caspase-8-inhibitory protein as a principal regulator of cell death and survival in human hepatocellular carcinoma. Lab Invest 83: 1033-1043, 2003. 
18. Schimmer AD, Welsh K, Pinilla C, Wang Z, Krajewska M, Bonneau MJ, Pedersen IM, Kitada S, Scott FL, Bailly-Maitre B, et al: Small-molecule antagonists of apoptosis suppressor XIAP exhibit broad antitumor activity. Cancer Cell 5: 25-35, 2004.

19. Ricci MS, Kim SH, Ogi K, Plastaras JP, Ling J, Wang W, Jin Z, Liu YY, Dicker DT, Chiao PJ, et al: Reduction of TRAIL-induced Mcl-1 and cIAP2 by c-Myc or sorafenib sensitizes resistant human cancer cells to TRAIL-induced death. Cancer Cell 12: 66-80, 2007.

20. Ravi R and Bedi A: Requirement of BAX for TRAIL/ Apo2L-induced apoptosis of colorectal cancers: Synergism with sulindac-mediated inhibition of Bcl-xL. Cancer Res 62: 1583-1587, 2002.

21. Hinz S, Trauzold A, Boenicke L, Sandberg C, Beckmann S, Bayer E, Walczak $\mathrm{H}$, Kalthoff $\mathrm{H}$ and Ungefroren $\mathrm{H}$ : Bcl-xL protects pancreatic adenocarcinoma cells against CD95- and TRAIL-receptor-mediated apoptosis. Oncogene 19: 5477-5486, 2000.

22. Kandasamy K, Srinivasula SM, Alnemri ES, Thompson CB, Korsmeyer SJ, Bryant JL and Srivastava RK: Involvement of proapoptotic molecules Bax and Bak in tumor necrosis factor-related apoptosis-inducing ligand (TRAIL)-induced mitochondrial disruption and apoptosis: Differential regulation of cytochrome $c$ and Smac/DIABLO release. Cancer Res 63 1712-1721, 2003.

23. Huang GJ, Deng JS, Chiu CS, Liao JC, Hsieh WT, Sheu MJ and $\mathrm{Wu} \mathrm{CH}$ : Hispolon protects against acute liver damage in the rat by inhibiting lipid peroxidation, proinflammatory cytokine, and oxidative stress and downregulating the expressions of iNOS, COX-2, and MMP-9. Evid Based Complement Alternat Med 2012: 480714, 2012

24. Chien YC, Huang GJ, Cheng $\mathrm{HC}, \mathrm{Wu} \mathrm{CH}$ and Sheu MJ: Hispolon attenuates balloon-injured neointimal formation and modulates vascular smooth muscle cell migration via AKT and ERK phosphorylation. J Nat Prod 75: 1524-1533, 2012.

25. Ali NA, Lüdtke J, Pilgrim H and Lindequist U: Inhibition of chemiluminescence response of human mononuclear cells and suppression of mitogen-induced proliferation of spleen lymphocytes of mice by hispolon and hispidin. Pharmazie 51: 667-670, 1996.

26. Lu TL, Huang GJ, Lu TJ, Wu JB, Wu CH, Yang TC, Iizuka A and Chen YF: Hispolon from Phellinus linteus has antiproliferative effects via MDM2-recruited ERK1/2 activity in breast and bladder cancer cells. Food Chem Toxicol 47: 2013-2021, 2009.

27. Huang GJ, Deng JS, Huang SS and Hu ML: Hispolon induces apoptosis and cell cycle arrest of human hepatocellular carcinoma Hep3B cells by modulating ERK phosphorylation. J Agric Food Chem 59: 7104-7113, 2011

28. Chen W, Zhao Z, Li L, Wu B, Chen SF, Zhou H, Wang Y and Li YQ: Hispolon induces apoptosis in human gastric cancer cells through a ROS-mediated mitochondrial pathway. Free Radic Biol Med 45: 60-72, 2008.

29. Huang GJ, Yang CM, Chang YS, Amagaya S, Wang HC, Hou WC, Huang SS and Hu ML: Hispolon suppresses SK-Hepl human hepatoma cell metastasis by inhibiting matrix metalloproteinase-2/9 and urokinase-plasminogen activator through the PI3K/Akt and ERK signaling pathways. J Agric Food Chem 58: 9468-9475, 2010

30. Chen W, He FY and Li YQ: The apoptosis effect of hispolon from Phellinus linteus (Berkeley \& Curtis) Teng on human epidermoid KB cells. J Ethnopharmacol 105: 280-285, 2006.

31. Sung B, Park B, Yadav VR and Aggarwal BB: Celastrol, a triterpene, enhances TRAIL-induced apoptosis through the downregulation of cell survival proteins and upregulation of death receptors. J Biol Chem 285: 11498-11507, 2010.

32. Yoshida T, Shiraishi T, Nakata S, Horinaka M, Wakada M, Mizutani Y, Miki T and Sakai T: Proteasome inhibitor MG132 induces death receptor 5 through CCAAT/enhancer-binding protein homologous protein. Cancer Res 65: 5662-5667, 2005.
33. Yamaguchi $\mathrm{H}$ and Wang HG: CHOP is involved in endoplasmic reticulum stress-induced apoptosis by enhancing DR 5 expression in human carcinoma cells. J Biol Chem 279: 45495-45502, 2004

34. Ichijo H: From receptors to stress-activated MAP kinases. Oncogene 18: 6087-6093, 1999.

35. Sarker M, Ruiz-Ruiz C and López-Rivas A: Activation of protein kinase $C$ inhibits TRAIL-induced caspases activation, mitochondrial events and apoptosis in a human leukemic T cell line. Cell Death Differ 8: 172-181, 2001.

36. Ozoren N, Kim K, Burns TF, Dicker DT, Moscioni AD and El-Deiry WS: The caspase-9 inhibitor Z-LEHD-FMK protects human liver cells while permitting death of cancer cells exposed to tumor necrosis factor-related apoptosis-inducing ligand. Cancer Res 60: 6259-6265, 2000.

37. Krammer PH: CD95's deadly mission in the immune system. Nature 407: 789-795, 2000.

38. Cummins JM, Kohli M, Rago C, Kinzler KW, Vogelstein B and Bunz F: X-linked inhibitor of apoptosis protein (XIAP) is a nonredundant modulator of tumor necrosis factor-related apoptosis-inducing ligand (TRAIL)-mediated apoptosis in human cancer cells. Cancer Res 64: 3006-3008, 2004.

39. Lee TJ, Lee JT, Park JW and Kwon TK: Acquired TRAIL resistance in human breast cancer cells are caused by the sustained cFLIP(L) and XIAP protein levels and ERK activation. Biochem Biophys Res Commun 351: 1024-1030, 2006.

40. Chawla-Sarkar M, Bae SI, Reu FJ, Jacobs BS, Lindner DJ and Borden EC: Downregulation of Bcl-2, FLIP or IAPs (XIAP and survivin) by siRNAs sensitizes resistant melanoma cells to Apo2L/TRAIL-induced apoptosis. Cell Death Differ 11: 915-923, 2004

41. Ravindran J, Subbaraju GV, Ramani MV, Sung B and Aggarwal BB: Bisdemethylcurcumin and structurally related hispolon analogues of curcumin exhibit enhanced prooxidant, anti-proliferative and anti-inflammatory activities in vitro. Biochem Pharmacol 79: 1658-1666, 2010.

42. Sung YH, Park KH, Lee YB, Park HM, Shin DJ, Park JS, Oh MS, Ma HI, Yu KH, Kang SY, et al: Midbrain atrophy in subcortical ischemic vascular dementia. J Neurol 256: 1997-2002, 2009.

43. Gupta SC, Francis SK, Nair MS, Mo YY and Aggarwal BB Azadirone, a limonoid tetranortriterpene, induces death receptors and sensitizes human cancer cells to tumor necrosis factor-related apoptosis-inducing ligand (TRAIL) through a p53 protein-independent mechanism: Evidence for the role of the ROS-ERK-CHOP-death receptor pathway. J Biol Chem 288 32343-32356, 2013.

44. Ravi R, Bedi GC, Engstrom LW, Zeng Q, Mookerjee B, Gélinas C, Fuchs EJ and Bedi A: Regulation of death receptor expression and TRAIL/Apo2L-induced apoptosis by NF-kappaB. Nat Cell Biol 3: 409-416, 2001

45. Shenoy K, Wu Y and Pervaiz S: LY303511 enhances TRAIL sensitivity of SHEP-1 neuroblastoma cells via hydrogen peroxide-mediated mitogen-activated protein kinase activation and upregulation of death receptors. Cancer Res 69: 1941-1950, 2009.

46. Wu GS, Burns TF, McDonald ER III, Jiang W, Meng R, Krantz ID, Kao G, Gan DD, Zhou JY, Muschel R, et al: KILLER/DR5 is a DNA damage-inducible p53-regulated death receptor gene. Nat Genet 17: 141-143, 1997.

47. Lu M, Xia L, Hua H and Jing Y: Acetyl-keto-beta-boswellic acid induces apoptosis through a death receptor 5-mediated pathway in prostate cancer cells. Cancer Res 68: 1180-1186, 2008.

48. Yodkeeree S, Sung B, Limtrakul P and Aggarwal BB: Zerumbone enhances TRAIL-induced apoptosis through the induction of death receptors in human colon cancer cells: Evidence for an essential role of reactive oxygen species. Cancer Res 69: 6581-6589, 2009. 